\title{
Catastrophic Floods - Possible Contribution of Groundwater due to Flash Reconstruction of the Rock Mass 3D-Cracknet under Seismic Factors
}

\author{
Tatiana Anatolievna Trifonova ${ }^{1}$, Dmitriy Vladimirovich Trifonov $^{2} \&$ Sergey Martirosovich Arakelian ${ }^{2}$ \\ ${ }^{1}$ Lomonosov Moscow State University, Moscow, Russia \\ ${ }^{2}$ Stoletovs Vladimir State University, Vladimir, Russia \\ Correspondence: Tatiana Anatolievna Trifonova, Lomonosov Moscow State University, Moscow, Russia. E-mail: \\ tatrifon@mail.ru
}

Received: November 29, 2014

Accepted: December 9, 2014

Online Published: April 25, 2015

doi:10.5539/mas.v9n6p76

URL: http://dx.doi.org/10.5539/mas.v9n6p76

\begin{abstract}
We studied the interaction of surface water and groundwater at the origin and development of catastrophic floods. Intense atmospheric precipitation is traditionally considered as the main factor of their occurrence. At the same time, we discuss the role of seismic processes as a factor that potentially influences on the occurrence of catastrophic floods. We made an analysis of the observed natural events, which confirm the impact of seismic activity on the state of groundwater and, therefore, on surface water. We also suggested an original approach to forecast the catastrophic floods on the basis of the analysis of seismic activity in respect of specific hydrological events that took place in 2013-2014.
\end{abstract}

Keywords: floods, groundwater, surface water, river basin, seismic activity

\section{Introduction}

Periodically, the world is experiencing the catastrophic floods, the scales of which far exceed the seasonal flood phenomena: they last for months and cause flooding areas of tens thousands of square kilometers. Prolonged heavy rains have traditionally been considered as the main cause of flooding (see example Berejnaya et al., 2013; Garambois et al., 2014). At the same time we concede the influence of other natural and anthropogenic factors. Environmental factors are the tsunamis, hurricanes and melting glaciers (including melting glaciers as a result of global warming), and anthropogenic factors are the errors in the design of hydraulic structures and the subsequent accidents on them, deforestation, etc. However, some factors that have no explicit, and indirect impact on the status of surface water are not considered.

Indeed, surface water, in fact, are part of the intricate hydrosphere of the Earth, which also includes groundwater (see. example Zektser et al., 2007) and atmospheric moisture in the vapor and condensed form. Depth of groundwater in the interior of the earth is hundreds of kilometers, and their volume, according to the latest data, is comparable (up to $16 \mathrm{~km}$ depth) and even greater than the volume of all the world's oceans (Smyth and Jacobsen, 2006). Ground waters are active participants in the water cycle: on the one hand, they absorb excess moisture coming from atmospheric precipitation; on the other hand, they feed surface waters during dry periods (Alley et al., 1999; Fleckenstein et al., 2010).

The lithosphere of the Earth also has a complex geological structure and is influenced by different forces: both endogenous and exogenous, so it is in constant dynamics, and obviously it has a significant impact on both groundwater and surface waters.

The role of seismic activity as one of the most important elements of the dynamics of the lithosphere and the processes occurring in the hydrosphere is well studied in the direction of the impact of hydrosphere processes on the state of the lithosphere (Kissin, 2009; Pinneker et al., 2010). As a rule we talk about changing in the chemical composition of groundwater as earthquake precursor (Igumnov and Stepanyan, 1989), earthquakes occur due to flooding of mines with water (Costain, 2008), the impact of groundwater status at the occurrence of earthquakes (González et al., 2012) et al. (major factors are discussed in details in Kissin, 2009; Pinneker et al., 2010). The reverse process - the impact of the dynamics of lithosphere processes on the state of the hydrosphere in general 
and its individual elements - are paid less attention. Analysis of this last factor of tectonic origin is given in this paper in terms of the potential causes that provokes catastrophic floods in certain areas under certain (usually rare) conditions.

\section{Method}

\subsection{Methodological Approach}

The following main points are taken as a basis in our study.

1) Feeding rivers with moisture is carried out not only through atmospheric precipitation, percolation and infiltration process in soil and the groundwater horizons, but also due to closer, often immediate connections with groundwater horizons through different systems of channel cracks that strike the rock and penetrate to a great depth (Jakob and Hungr 20; McClymont et al., 2011). In this regard, we can say that the river basin is a stable, functionally connected, dynamic 3D-hydrological system (Trifonova, 1994; Trifonova, 2008).

(2) The effect of the seismic processes impact on the state of both groundwater and surface water can occur over long distances of thousand kilometers or more. In fact, at present, this coupting refers to directly observable, and many phenomena are interpreted from these positions. As an example, we can give the earthquake in Tohoku region, Japan, March 11, 2011, which led to the origination of resonant seiches in the fjords of Norway (Bondevik et al., 2013). Moreover, the observation of the control artesian well in Christiansburg, Virginia, USA, in which regular measurements of water levels are made, demonstrates synchronous rise of water level in the well after earthquakes occurring even on the opposite side of the earth, including after the earthquake in Tohoku region, Japan (Hydrologic Response in Well 27F2 SOW 019 to Worldwide Earthquakes: NEAR THE EAST COAST OF HONSHU, JAPAN, Mar 11, 2011, M9.0 earthquake, 2014).

There is no doubt in the fact of the influence of seismic waves on water levels in underground water basins, and therefore - on the state of the surface water bodies. At the same time we focus on the other side of the process, as a result of seismic waves passage through the earth's crust, the topology of 3D-fractures net can change, these nets are transportation routes for the transition of groundwater. The key here are the changes in the hydraulic connection between different water bodies in accordance with the changing map of hydrostatic and hydrodynamic pressures in the underground water basins, especially - with complex configuration.

(3) The basins in which the underground water is close to the surface, can more likely cause catastrophic flooding due to the fact that they provide more favorable conditions for releasing the groundwater to the surface at various perturbations.

\subsection{Objects of research}

In the study, we analyzed the conditions under which some of the catastrophic floods in 2013-2014 emerged and developed: Flooding in Western Europe in May and June 2013; flooding in the Amur region, Russia, in September-October 2013; flooding in the state of Colorado, USA, in September-October 2013; flooding in the UK in October 2013 - March 2014; Flooding in Serbia in April-May 2014 and the flooding in the Altai region, Russia, in May-June 2014.

\subsection{Data Base}

We used the following actual data for analysis.

(1) We studied the meteorological and climatic conditions in the areas where the considered hydrological disasters took place, according to the existing literature data and materials from the official site of Gismeteo (GISMETEO.RU: Weather in Russia ..., 2014).

(2) A catalog, published on the official website of the German Research Center for Geosciences (GEOFON Program GFZ Potsdam: GFZ Potsdam - Earthquake Bulletin, 2014), is the primary source of information about earthquakes. In addition, we used information about the tectonic features of the studied area: we considered the location of the lithosphere plates and the dynamics of their condition, as well as variations of seismic waves propagation, since a significant differential of the properties of the environment at the boundaries of division of different lithosphere plates can cause absorption / reflection / refraction of a significant part of the energy of the propagating seismic waves (Leonov, 2008). This suggests a minor influence of seismic activity on underground hydrosphere from the other side of the division boards.

(3) In order to assess the hydrological situation, we used the maps published on the official website of the World-wide Hydrogeological Mapping and Assessment Programme (BGR - Global groundwater maps, 2014). The source of data on floods were the available to us by both academic publications (see e.g. Berejnaya et al., 2013; Gartsman et al., 2014; Danilov-Danilyan and Gelfan, 2014; Hramova and Parshina, 2013), and numerous 
reports of informational-analytical agencies and eyewitness accounts.

\subsection{Methods}

In order to assess the coherence of the two events - earthquakes and floods - we firstly, carried out the calculation of the coefficient of correlation between (a) earthquakes' magnitudes and time delays for the associated water disasters, and (b) earthquakes' magnitudes and distances to areas where there have been water disasters. Secondly, we made an attempt to visualize the alleged dependences in a visual form using geographical maps with marking on them the potentially dangerous areas. "Paired" earthquakes and floods were identified by the principle of maximum proximity of the epicenter of a fairly strong earthquake (with a magnitude of at least 4) to the area of the most severe manifestations of the catastrophic flooding. At the same time the maximum delay in time in our model was limited by an interval of 30 days, since the attempt of simultaneous accounts of many earthquakes occurring over a longer time period would complicate the identification of key influencing parameters (we previously had a selective analysis of many important events, starting almost from the beginning of the last century, which allowed us to statistically determine the preferred time interval).

\section{Results}

We analyzed the information on meteorological and climatic conditions on the territories under consideration during the catastrophic floods (Berejanaya et al., 2013, Hramova and Parshina, 2013). Obviously, as it usually happens during floods, all the events were preceded by strong atmospheric precipitations. We analyzed the variations of atmospheric pressure for several years in the Amur region and Altai Krai (compare with data of Danilov-Danilyan and Gelfan, 2014). Figure 1 shows the variations of atmospheric pressure in the settlements Ivanovka (Amur Region, Russia) and Ust-Kalmanka (Altai Krai, Russia).
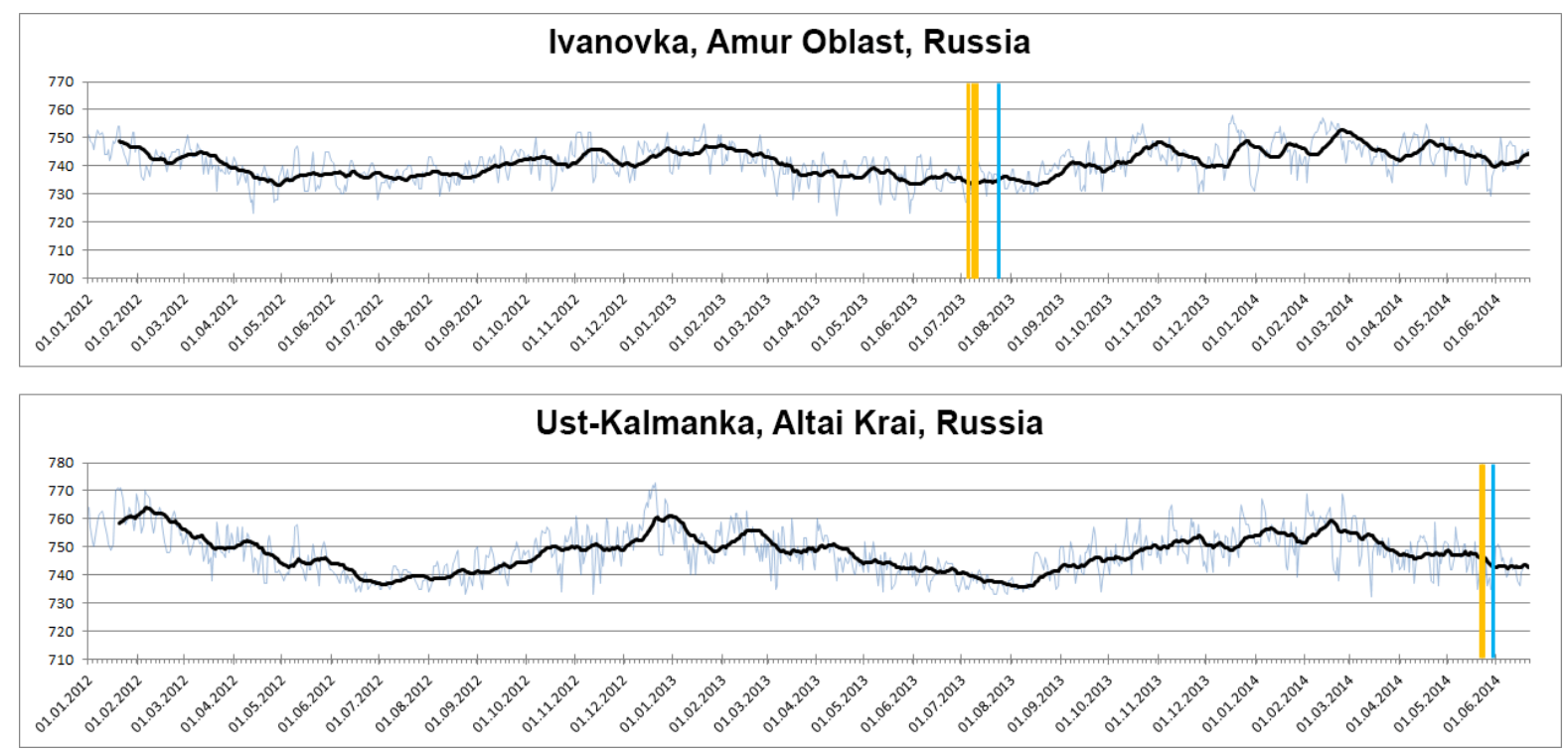

Figure 1. Graphics of atmospheric pressure in settlements Ivanovka (above) and Ust-Kalmanka (below) for the 2012-2014: thin dull blue broken lines - dependences of the daily average atmospheric pressure; bold dark blue broken lines - linear filtrations (averaging) of the graphics of atmospheric pressure in 20 points; orange vertical lines - cutoffs corresponding to the dates of earthquakes; blue vertical lines - cutoffs corresponding to the dates

of the first mentions of floods

In addition, the results of our analysis revealed that all these floods can be associated with the preceding strong earthquakes, which we believe to have played a significant role in the origin and development of catastrophic water situations on the ground surface.

A summary of floods and earthquakes associated with them is given in Table 1. It contains information about dates and locations (latitude, longitude) of the disasters, earthquakes magnitudes, and gives an overview of the alleged related groups of events. 
Table 1. General information on the analyzed disasters

\begin{tabular}{|c|c|c|c|c|c|}
\hline \multirow{2}{*}{$\begin{array}{l}\text { Conjugate } \\
\text { group of } \\
\text { events }\end{array}$} & \multirow[b]{2}{*}{ \# } & \multirow{2}{*}{$\begin{array}{r}\text { Catastrophe, date, place (latitude - } \\
\text { in the northern hemisphere; } \\
\text { longitude - from the meridian of } \\
\text { Greenwich) }\end{array}$} & \multirow{2}{*}{$\begin{array}{r}\text { Magnitude } \\
\text { of the } \\
\text { earthquake }\end{array}$} & \multicolumn{2}{|c|}{$\begin{array}{r}\text { Two associated events: } \\
\text { earthquake and flooding }\end{array}$} \\
\hline & & & & $\begin{array}{r}\text { Time delay, } \\
\text { days }\end{array}$ & $\begin{array}{l}\text { Distance, } \\
\text { thousands } \\
\mathrm{km}\end{array}$ \\
\hline \multirow{3}{*}{1} & 1 & $\begin{array}{l}\text { Earthquake on } 05 / 16 / 2013 \text { Ula, } \\
\text { Turkey }(36.4: 27.2)\end{array}$ & 5 & 9 & 2.1 \\
\hline & 2 & $\begin{array}{r}\text { Earthquake on 05/19/2013 North } \\
\text { Algeria }(36.9 ; 5.1)\end{array}$ & 5.1 & 6 & 1.6 \\
\hline & 3 & $\begin{array}{r}\text { Flooding on } 25 / 05 / 2013 \text { Erfurt, } \\
\text { Germany }(51 ; 11)\end{array}$ & & & \\
\hline \multirow{6}{*}{2} & & Earthquake on $07 / 04 / 2013$ & 5 & 19 & 1.3 \\
\hline & 4 & $\begin{array}{r}\text { Nevelsk, Sakhalin, Russia (46.7, } \\
141.9)\end{array}$ & & & \\
\hline & 5 & $\begin{array}{r}\text { Earthquake on } 07 / 07 / 2013 \text { kurilsk, } \\
\text { Sakhalin, Russia }(44.5,147.9)\end{array}$ & 4.4 & 16 & 1.8 \\
\hline & 6 & $\begin{array}{r}\text { Earthquake on 09/07/2013 } \\
\text { Nevelsk, Sakhalin, Russia (46.7, }\end{array}$ & 2.9 & 14 & 1.3 \\
\hline & 7 & $\begin{array}{r}141.9) \\
\text { Earthquake on } 21 / 07 / 2013 \\
\text { Kitaibaraki, Japan }(36.2,141.4)\end{array}$ & 4.8 & 2 & 2.2 \\
\hline & 8 & $\begin{array}{l}\text { Flooding on 23/07/2 } \\
\text { Amur Region, Russi }\end{array}$ & $\begin{array}{l}3 \text { Ivanovka, } \\
53.6,126.7)\end{array}$ & & \\
\hline \multirow{6}{*}{3} & 9 & $\begin{array}{r}\text { Earthquake on } 27 / 08 / 2013 \text { Plumas, } \\
\text { California, USA }(39.8,-120.1)\end{array}$ & 4.2 & 16 & 1.3 \\
\hline & & Earthquake on $28 / 08 / 2013$ & 4.3 & 15 & 1.4 \\
\hline & 10 & $\begin{array}{r}\text { Saucillo, Chihuahua, Mexico } \\
(27.8,-105.7)\end{array}$ & & & \\
\hline & 11 & $\begin{array}{r}\text { Earthquake on } 09 / 02 / 2013 \text { Panola, } \\
\text { Texas, USA }(32 ;-94.4)\end{array}$ & 4.5 & 10 & 1.3 \\
\hline & & Flooding on 12/09/2013 Boulder, & & & \\
\hline & 12 & $\begin{array}{r}\text { Colorado, USA } \\
(40 ;-105.3)\end{array}$ & & & \\
\hline \multirow{4}{*}{4} & 13 & $\begin{array}{l}\text { Earthquake on } 10 / 13 / 2013 \text { the } \\
\text { South of Iceland }(63.7,-22.7)\end{array}$ & 5.2 & 15 & 1.8 \\
\hline & 14 & $\begin{array}{r}\text { Earthquake on } 15 / 10 / 2013 \\
\text { Romania }(45.7 ; 26.6)\end{array}$ & 4.8 & 13 & 2.2 \\
\hline & & Flooding on 10/28/2013 & & & \\
\hline & 15 & $\begin{array}{r}\text { Weymouth, United Kingdom } \\
(50.6,-2.5)\end{array}$ & & & \\
\hline \multirow{3}{*}{5} & 16 & $\begin{array}{r}\text { Earthquake on } 14 / 04 / 2014 \text { Crete, } \\
\text { Greece }(34.1 ; 25.9)\end{array}$ & 5.1 & 5 & 1.1 \\
\hline & 17 & $\begin{array}{r}\text { Earthquake on } 04 / 16 / 2014 \\
\text { southwest of Turkey }(36.2 ; 31.4)\end{array}$ & 4.5 & 3 & 1.2 \\
\hline & 18 & $\begin{array}{r}\text { Flooding on } 19 / 04 / 2014 \\
\text { Krusevac, Serbia }(43.6 ; 21.3)\end{array}$ & & & \\
\hline \multirow{10}{*}{6} & 19 & Earthquake on $21 / 05 / 2014$ & 5.2 & 9 & 3.6 \\
\hline & & $\begin{array}{r}\text { Southwestern Iran }(29.6 ; 50.9) \\
\text { Earthquake on } 21 / 05 / 2014\end{array}$ & 4.6 & 9 & 1.9 \\
\hline & 20 & $\begin{array}{r}\text { northeastern Afghanistan (36.6; } \\
70.8)\end{array}$ & & & \\
\hline & & Earthquake on 23/05/2014 Muysky & 5.4 & 7 & 2.1 \\
\hline & 21 & District, Buryatia, Russia (56.1, & & & \\
\hline & & $\begin{array}{r}114.1) \\
\text { Flooding on 30/05/2014 }\end{array}$ & & & \\
\hline & 22 & Charyshsky, Altay, Russia (51.4; & & & \\
\hline & 23 & $\begin{array}{r}\text { Flooding on } 06 / 04 / 2014 \text { Huaihua, } \\
\text { southeast of China }(27.5,109.9)\end{array}$ & & & \\
\hline & & The rise of the water level by 103 & & & \\
\hline & 24 & $\begin{array}{r}\text { cm 06.15.2014 } \\
\text { Caspian Sea }(46.2 ; 51.5)\end{array}$ & & & \\
\hline
\end{tabular}

Further, Table 2 shows the results of calculation of correlations (average values) between both earthquakes' magnitudes and time delays (in days), and between earthquakes' magnitudes and distances (in thousand $\mathrm{km}$ ) for 
earthquakes and the associated water disasters: the first column contains ordered by value (ascending) earthquakes' magnitudes; the second - the time delay (in days) between the dates of earthquakes and the dates of the first mentions of the floods; the third - the distance between the epicenters of earthquakes and the fixed places of floods (we usually talk about settlements exposed to the greatest shock of the water element). The bottom row of the table shows the results of calculations for the corresponding correlation coefficients (signs «+» and «-» define direct - increasing, or inverse - decreasing, dependences with the increasing of earthquakes' magnitudes, accordingly).

Table 2. Data base and correlations between both "magnitude / time delay" and "magnitude / distance" for two conjugate events - earthquakes and floods

\begin{tabular}{ccc}
\hline Earthquake magnitude & \multicolumn{2}{c}{ Two associated events: earthquake and flooding } \\
Time delay, days & Distance, thusands km \\
\hline 2.9 & 14 & 1.3 \\
4.2 & 16 & 1.3 \\
4.3 & 15 & 1.4 \\
4.4 & 16 & 1.8 \\
4.5 & 10 & 1.3 \\
4.5 & 3 & 1.2 \\
4.6 & 9 & 1.9 \\
4.8 & 2 & 2.2 \\
4.8 & 13 & 2.2 \\
5.0 & 9 & 2.1 \\
5.0 & 19 & 1.3 \\
5.1 & 6 & 1.6 \\
5.1 & 5 & 1.1 \\
5.2 & 15 & 1.8 \\
5.2 & 9 & 3.6 \\
5.4 & 7 & 2.1 \\
The correlation coefficient & $\mathbf{- 0 . 3 1}$ & $+\mathbf{0 . 4 1}$ \\
\hline
\end{tabular}

Some illustrative materials in the frames of proposed concept are shown in Figures 2, 3.

Figure 2 shows images that visualize connections between events within the designated groups of events relevant to flooding in Western Europe - Figure 2a, Amur Region (Russia) - Figure 2b, and the state of Colorado (USA) - Figure 2c. Within the framework of the presented model, the propagation of seismic waves is for simplicity considered to be isotropic and independent of the properties of the propagation medium. 

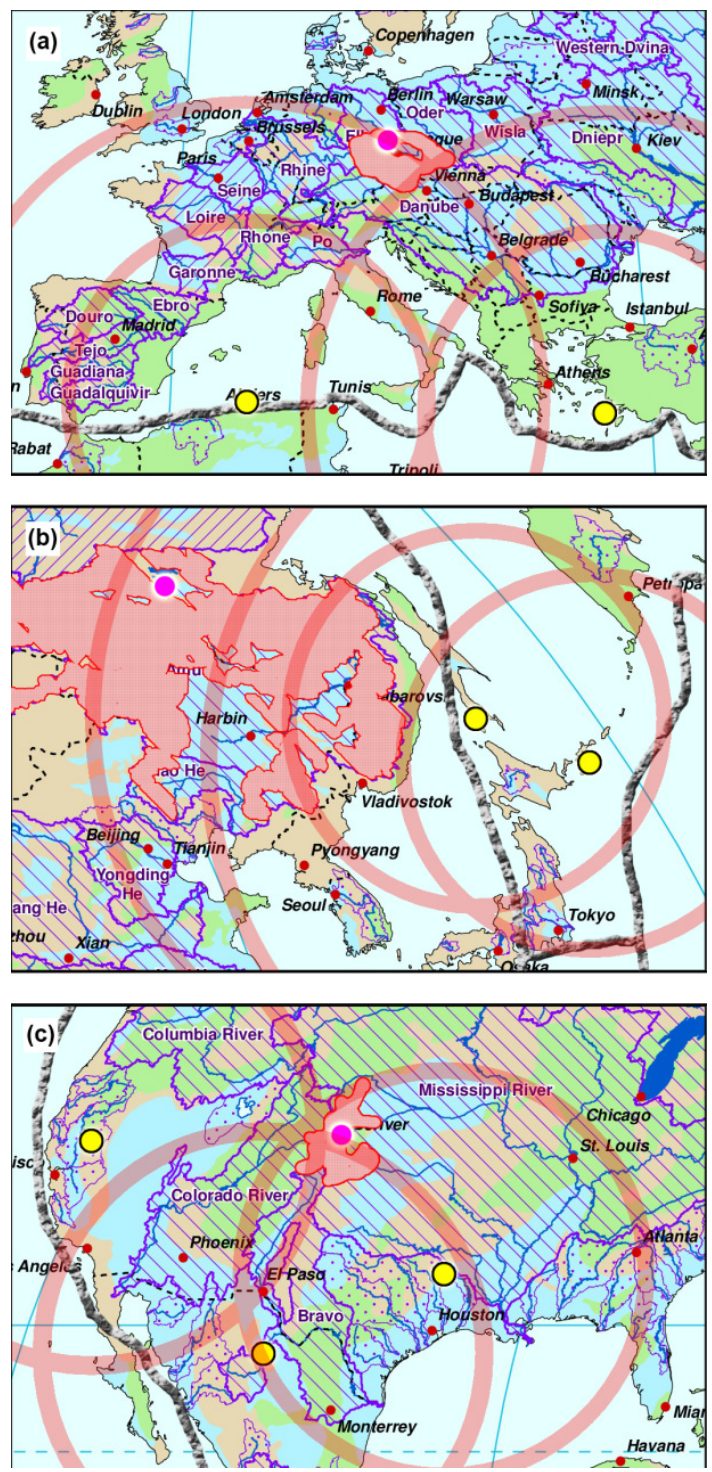

Figure 2. The characteristic parameters that affect the relationship between earthquakes and floods: a) Flooding in Western Europe in 2013; b) flooding in the Amur region, Russia, in 2013; c) flooding in Colorado, USA, in 2013

Blue shading - underground basins of rivers and lakes in the earth's crust; blue filling - groundwater in the major underground basins; green filling - groundwater in complex hydro geological structures; beige filling groundwater in local shallow aquifers; thick gray curves - boundaries of lithosphere plates; yellow circles - the epicenters of the earthquakes; translucent red circles - a schematic representation of fronts of propagating of seismic waves; pink filling with red border - potentially dangerous areas; purple circles with white border fixed locations of floods.

Figure 3 shows images that visualize connections between events in other groups of disasters, which are relevant to flooding in the UK - Figure 3a, Serbia - Figure 3b, and the Altai region (Russia) - Figure 3c. Compared with Figure2, the visualization in Figure 3 was modified in order to get more reasonable labeling of potentially dangerous areas for more reasonable forecasts. The main difference between Figure 2 and Figure 3 are in the form of designation of the zones of seismic waves interaction: in Figure 2 they were marked by translucent red circles, but in Figure 3 they are marked with translucent red gradient lines. They run perpendicular to the lines joining the epicenters of earthquakes, exactly in the middle. We assume that the areas lying midway between the epicenters of the earthquakes are at greatest influence of seismic waves, due to the effects of interference of waves of comparable amplitudes. 
(a)

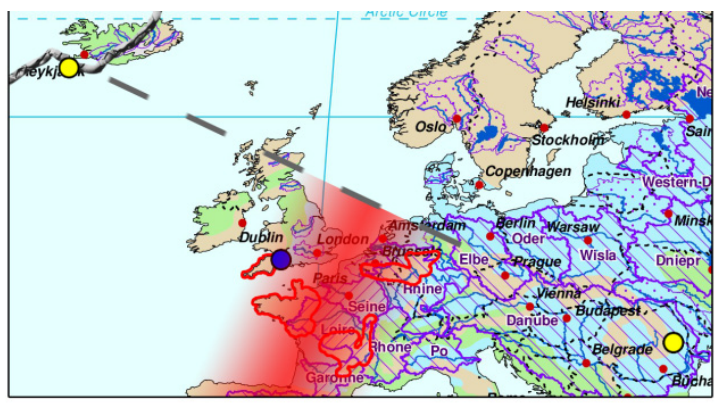

(b)
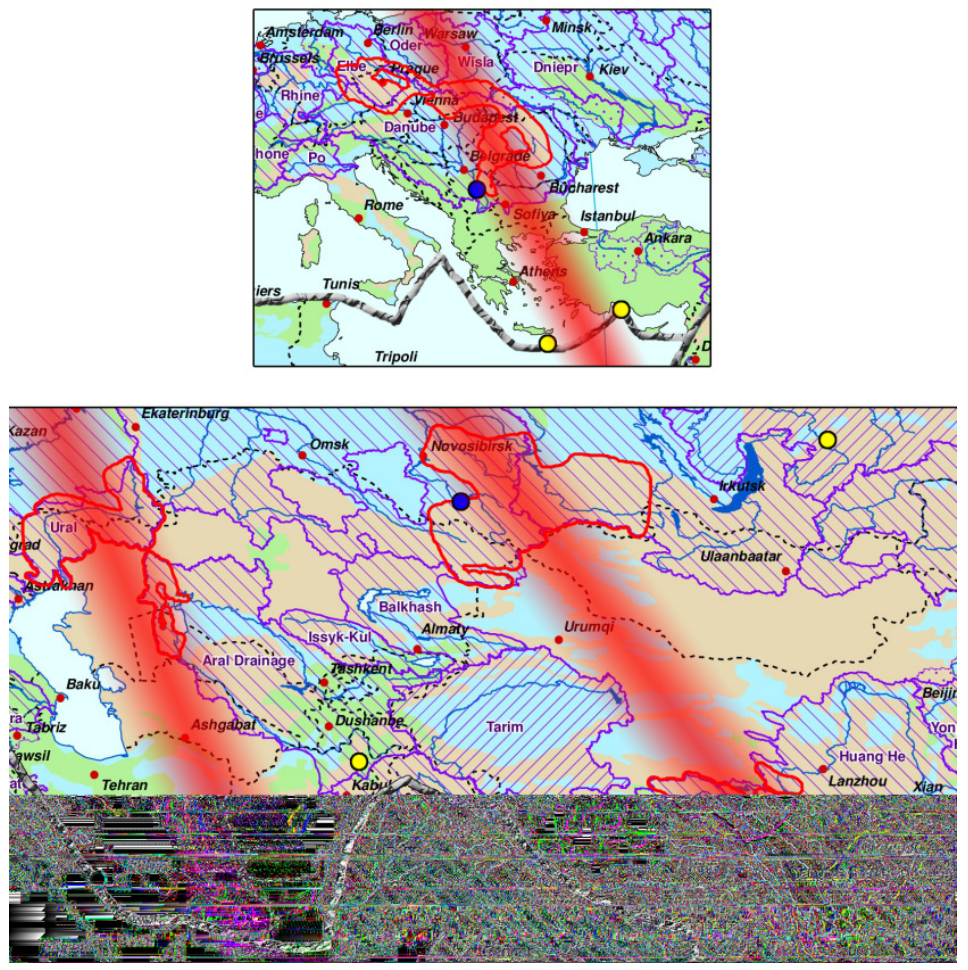

Figure 3. Localization of dangerous areas - taking into account the accrued earthquakes and floods: a) flooding in the UK in 2013-2014; b) Flooding in Serbia in 2014; c) flooding in the Altai region, Russia, in 2014

Blue shading - underground basins of rivers and lakes in the earth's crust; blue filling - groundwater in the major underground basins; green filling - groundwater in complex hydro geological structures; beige filling groundwater in local shallow aquifers; thick gray curves - boundaries of lithosphere plates; yellow circles - the epicenters of the earthquakes; translucent red gradient lines - line of the greatest impact of the earthquakes; red edges - potentially dangerous areas; blue circles - fixed places of floods.

\section{Discussion}

On the one hand, a catastrophic flood that involved much of Western Europe was accompanied by a sharp cyclonic activity of the atmosphere with a pronounced decrease in the atmospheric pressure. On the other hand, the analysis of Figure 1 shows that there were no particular anomalies in atmospheric pressure during floods in Russia (Amur region in 2013 and in the Altai Territory in 2014): we noted only traditional summer drop in pressure, which, even in comparison with previous years shows that the situation was completely normal. In other words, it is problematic to talk about the existence of any special zones (in the form of low pressure areas), which could attract (attractors) anomalously intense rainfall.

We would like to draw particular attention to the fact that there was no convincing evidence of the correspondence of rainfall in the Amur region with the quantity of water which was manifested in the water flow during floods; it means that this water balance requires additional sources. However, it should be noted that experts point to a big water content of soils in the basin of the Amur River in autumn of 2012, which, of course, 
played a role in strengthening the flood (compare with Gartsman et al., 2014; Danilov-Danilyan and Gelfan, 2014) and may be associated with changes in the hydrological regime of the region, although there is no complete clarity in this question.

The analyzing of the correlation data gives interesting results (see. Table. 2), which is not great - about 0.3-0.4 but it is yet significant and determines the existing trend: for the pair of "magnitude / time delay", the higher the magnitude of the earthquake, the earlier we hear about it (indicated by the sign "-"), and for the pair of "magnitude / distance", the higher the magnitude of the earthquake, the greater the distance of its effects (marked by "+" sign).

In other words, the correlation coefficients allow us to make rough estimates of how long and at what distance after a significant earthquake we can expect the new water-related disasters, but they are not suitable for marking potentially dangerous areas, as they do not identify a preferred direction for the areas of risk. For these purposes, visualization is more appropriate, based on the location of earthquake epicenters. Here we can distinguish three cases that have some features in terms of identifying potentially dangerous areas, and which can reduce all other cases.

Let us illustrate the first case using the example of flooding in the Amur region (Russia) in 2013 (Figure 2b). In this case, the earthquake epicenters were located close to each other in the same geographical area, which is bounded on the west by the boundary between the Eurasian and North American lithosphere plates, and in the east - by the boundary between the North American and Pacific plate (see e.g. Leonov, 2008; GEOFON Program GFZ Potsdam: GFZ Potsdam - Earthquake Bulletin, 2014). An important fact is that on the western boundary these tectonic plates shift in the same direction, so we suggest that differential properties of the medium and, therefore, the mentioned above quenching effect is not as significant as on the eastern border, where the North American plate "dashes" against the Pacific one. In addition, to the east lies the Pacific Ocean, which makes it possible for seismic waves that propagate to the east, to relax (in the aquatic environment seismic waves have less speed and they are damped because they stimulate wave disturbances (Kissin, 2009; Pinneker et al., 2010) ).

As for the western direction, here seismic waves propagate on the continental crust, and taking into account the multiplicity of earthquakes, obviously, they could appear much stronger due to the effect of seismic waves interference. The nearest regions of local, shallow, groundwater were Amur Region (Russia) and northeast of China, where then there was a catastrophic flood (cf. Danilov-Danilyan and Gelfan 2014).

On the example of flood in Western Europe in 2013 (Figure 2a), let us consider the second case. In this case there were two earthquakes, the epicenters of which were located at a considerable distance from each other. Here seismic waves, which were moving from the earthquake in Algeria to the east, met with seismic waves that were moving from the earthquake in Turkey in the west. As we said before, in our model we assume that the most affected with this kind of seismic waves will be in the area located in the middle between the two epicenters. This area, in this case was the south of Germany, where the most catastrophic flood accrued, in fact.

Twists and breaks of the boundaries of lithosphere plates can be very important in this approach. For example, the break, which runs along the western border of Greece, in this example, could protect almost all of France and Spain from seismic waves incurred during the earthquake in Turkey. The same are around such groups of disasters associated with floods, firstly, in the UK in 2013-2014 (here, perhaps, we can see how breaking of the boundaries of lithosphere plates near Iceland protected Scandinavia from the effects of earthquake in Iceland); Second - in Serbia in 2014 (despite the fairly close positioning of earthquakes epicenters) and thirdly - even in the Altai region in 2014 (where three earthquakes accrued, but they were located at a considerable distance from each other and interestingly, almost in a straight line, which led to the fact that seismic waves from the earthquake in Afghanistan in the west met with seismic waves from the earthquake in Iran, and in the east - with seismic waves from the earthquake in Buryatia, Russia).

Finally, let us illustrate the third case using the example of flood in Colorado, USA, in 2013. In this case, three earthquakes' epicenters were located almost in the shape of a triangle, so the potentially dangerous zone was located exactly at the geometric center of the triangle - at the intersection of the circles with the centers at the epicenters of the earthquakes. This area subsequently was affected by the greatest shock of the water element (Figure 2c).

From the standpoint of convenience and accuracy of forecasting, the third case is the most favorable, because it clearly determines the potentially dangerous area. In this case, it is determined by the combination of circumstances, when at the intersection of three circles of seismic processes there is, or there is no region of localization a local shallow groundwater. However, this third case is still a rare phenomenon; Earthquake in 
Texas, in our opinion, can be classified as "atypical", because of both its distance from the seismically active zones and the location of the boundaries of lithosphere plates. Therefore, the first or second cases that we have considered most characteristic for the events defined by the relation between earthquakes and the groundwater access to outside.

We would like to draw particular attention to the fact that catastrophic hydrological processes tend to lead to a great material damage, they are often the cause of humanitarian disasters, and, of course, they require a careful study of natural and technological conditions in a particular area in the current trends, and in the long term. The investigation of possible (often complex) causes, the identification of risk areas and prognostic evaluation of the force of the flooding to mitigate the consequences of catastrophic floods, requires, above all, accurate databases and integrated approaches in monitoring the states and processes developing in the atmosphere, underground hydrosphere, and in general - in the lithosphere. In its entirety, this task today is hardly soluble even with the use of reasonable hypotheses and proposals for modeling of the situation using modern high performance computational tools.

And at the same time, any progress in this direction is important. In this aspect, we have proposed a possible approach for the consideration and analysis of catastrophic floods taking into account the fundamental geodynamic, hydro geological and hydrological factors influencing on their occurrence.

\section{Conclusion}

Integral and united 3D atmo-hydro-litho self-organizing system of the river basin is always in dynamic, and the identification of factors that control its condition (by different parameters) is a principal scientific field. It is very important that in the occurring (by various reasons) of a stress condition in this system, in particular, a sharp rise in groundwater levels as a result of, for example, extreme precipitation, and in terms of an additional factor - as the targeting of seismic waves - a mutual enhancement of different processes in a certain territory is possible. Because of these complicated resonance phenomena, the underground water tank gets an extreme dynamic impulse that can lead to a splash of groundwater to the surface and cause catastrophic flooding (both flash and continuous).

So, the seismic activity, which is traditionally considered in geological and geomorphologic aspects, needs a deeper study in terms of its impact on the hydrological processes in the Earth's interior and on surface water. This requires a consideration of many factors of earthquakes' effects, and geological characteristics of the mediums in which there is a propagation of seismic waves. A separate issue in this case - the recovery mode of groundwater river basins and the effect on it (direct or indirect) of earthquakes as possible causes, determining the state of underground hydrosphere and its role in the development of catastrophic floods. The processes are the spatially distributed with feedback (positive and/or negative in time).

Thus, the paper suggests an original approach to explain and predict the processes of a flood and/or mudflow (debris) formation and spreading out over the river beds in mountain conditions under both the flash and continuous increase of water masses involved (being strongly above the precipitations intensity) due to the groundwater and surface water interaction. The 3D crack-net in the frames of unified rivershed basin in a mountain massif, is a transportation system (varied by some dynamic stress factors) for a groundwater due to hydrostatic/ hydrodynamic pressure distribution in terrestrial bowels. The main reasons for such a dramatical rise of the pressure and/or reconstruction of the 3D-crack-net transportation system can be associated with seismic processes. Under this concept we carried out the analysis of seismic activity in respect of specific hydrological events that took place in 2013-2014.

The approach (and the conception around) can result in more reasonable forecast and early warning for the natural water hazard/disaster taking into account the groundwater dominant role in dynamic under some external factors.

For this item the continuous monitoring of the state of underground hydrosphere should be carried out, e.g. by drilling artesian wells on a specific strategies in potentially dangerous areas (including those identified using our approach) followed by the synchronous measurements of water levels and pressures in the water table of different depths of water (especially "before" and "after" water disaster occurred).

\section{Acknowledgments}

Scientific publication is prepared within the frameworks of the state task of VISU № 37.2108.2014 / K to perform state works in the field of scientific activity. 


\section{References}

Alley, W. M., Reilly, T. E., \& Franke, O. L. (1999). Sustainability of ground-water resources. Denver, U.S. Government Printing Office. ISBN 0-607-93040-3.

Berejnaya, T. V., Golubev, A. D., \& Parshina, L. N. (2013). Abnormal weather events in the territory of the Russian Federation in July 2013. Meteorology and Hydrology, 10, 114-123. Retrieved from http://planet.rssi.ru/mig/

BGR - Global groundwater maps. B BGR - Whymap. Retrieved in September 30, 2014, from http://www.whymap.org/whymap/EN/Downloads/Global_maps/globalmaps_node_en.html

Bondevik, S., Gjevik, B., \& Sorensen, M. B. (2013). Norwegian seiches from the giant 2011 Tohoku earthquake, Geophysical Research Letters, 40, 3374-3378. http://dx.doi.org/10.1002/grl.50639.

Costain, J. K. (2008). Intraplate seismicity, hydro seismicity, and predictions in hindsight, Seismology Research Letters, 79, 579-589. http://dx.doi.org/10.1785/gssrl.79.4.578

Danilov-Danilyan V. I., \& Gelfan, A. N. (2014). Catastrophic floods in 2013 in the Amur River basin: Formation conditions, assessment of repeatability, the results of modeling, Water resources, 41, 111-122. http://dx.doi.org/10.7868/S0321059614020059

Fleckenstein, J. H., Krause, S., Hannah, D. M., \& Boano, F. (2010). Groundwater-surface water interactions: New methods and models to improve understanding of processes and dynamics, Advances in Water Resources, 33, 1291-1295. http://dx.doi.org/10.1016/j.advwatres.2010.09.011

Garambois, P. A., Larnier, K., Roux, H., Labat, D., \& Dartus, D. (2014). Analysis of flash flood-triggering rainfall for a process-oriented hydrological model, Atmospheric Research, 137, 14-24. http://dx.doi.org/10.1016/j.atmosres.2013.09.016

Gartsman, B. I., Mezentceva, L. I., Menovschikova, T. S., \& Popova, N. Y. (2014). Conditions of formation of extremely high water content in rivers of Primorye in autumn-winter 2012, Meteorology and Hydrology, 4, 77-92. Retrieved from http://planet.rssi.ru/mig/

GEOFON Program GFZ Potsdam: GFZ Potsdam - Earthquake Bulletin. B GEOFON Program GFZ Potsdam: GEOFON Main page. Retrieved in September 30, 2014, from http://geofon.gfz-potsdam.de/eqinfo/list.php

GISMETEO.RU: Weather in Russia. Exact Weather forecast (weather forecast) for today, tomorrow, weekend, week, month. GISMETEO.RU: Weather in Russia. Exact Weather forecast (weather forecast) for today, tomorrow, weekend, week, month. Retrieved in September 30, 2014, from http://www.gismeteo.ru/

González, P. J., Tiampo, K. F., Palano, M., Cannavó, F., \& Fernández, J. (2012). The 2011 Lorca earthquake slip distribution controlled by groundwater crustal unloading, Nature Geoscience, 5, 821-825. http://dx.doi.org/10.1038/ngeo1610

Hydrologic Response in Well 27F2 SOW 019 to Worldwide Earthquakes: NEAR THE EAST COAST OF HONSHU, JAPAN, Mar 11, 2011, M9.0 earthquake. In USGS Virginia Water Science Center: Public page. Retrieved in September 30, 2014, from http://va.water.usgs.gov/earthquakes/20110311a.html

Igumnov, V. A., \& Stepanian, G. Z. (1989). Some hydrogeochemical aspects of the Spitak earthquake. Proceedings of the Academy of Sciences of the Armenian SSR, Earth Sciences, 3, 24-33. ISSN 0515-961X.

Jakob, M. \& Hungr, O. (2005). Debris-flow Hazards and Related Phenomena. New York, Springer. ISBN 978-3-540-20726-9.

Khramova, L. K., \& Parshina, L. N. (2013). Weather on the territory of the Russian Federation in July 2013, Meteorology and Hydrology, 10, 110-113. Retrieved from http://planet.rssi.ru/mig/

Kissin, I. G. (2009). Fluids in the earthcrust: geophysical and tectonic aspects. Moscow, Nauka. ISBN 978-5-02-036655-8.

Leonov, M. G. (2008). Tectonics of consolidate crust. Moscow, Nauka. ISBN 9785020357808.

McClymont, A. F., Roy, J. W., Hayashi, M., Bentley, L. R., Maurer, H., \& Langston, G. (2011). Investigating groundwater flow paths within proglacial moraine using multiple geophysical methods, Journal of Hydrology, 399, 57-69. http://dx.doi.org/10.1016/j.jhydrol.2010.12.036

Pinneker, E. V., Howard, D. E., \& Harvey, J. C. (2010). General Hydrogeology. Cambridge, Cambridge University Press. ISBN 0521154839. 
Smyth, J. R., \& Jacobsen, S. D. (2006). Nominally anhydrous minerals and Earth's deep water cycle, Earth's Deep Water Cycle, Geophysical Monograph Series, 168, 13-28. http://dx.doi.org/10.1029/GM168

Trifonova, T. A. (1994). Mountain river channel: energy model of development. Reports of the Russian Academy of Sciences, 3, 334-338. ISSN 0869-5652.

Trifonova, T. A. (2008). River drainage basin as a natural self-organizing geosystem. Proceedings of the Russian Academy of Sciences. Geographical Series, 1, 28-36. ISSN 0373-2444.

Zektser, I. S., Everett, L. G., \& Dzhamalov, R. G. (2007). Submarine groundwater. NW, Taylor \& Francis Group. ISBN 0-8493-3576-0.

\section{Copyrights}

Copyright for this article is retained by the author(s), with first publication rights granted to the journal.

This is an open-access article distributed under the terms and conditions of the Creative Commons Attribution license (http://creativecommons.org/licenses/by/3.0/). 